\title{
OPTIMISME SEBAGAI MEDIATOR HUBUNGAN ISOLASI SOSIAL DENGAN DEPRESI PADA MASA PANDEMI COVID-19
}

\author{
Vella Fitrisia Agustina ${ }^{1}$ dan Indah Megawati Aswin ${ }^{2}$ \\ ${ }^{1}$ Fakultas Psikologi Universitas Tama Jagakarsa \\ Jl. TB Simatupang No. 152, Jagakarsa, Kota Jakarta Selatan 12530 \\ ${ }^{2}$ Alumni Magister Sains Psikologi Sosial Universitas Gadjah Mada \\ Jl. Sosio Humaniora Bulaksumur, Sleman, Daerah Istimewa Yogyakarta \\ E-mail: fitrisia.a@gmail.com
}

\begin{abstract}
ABSTRAK
Pandemi Covid-19 yang melanda di hampir seluruh penjuru dunia, termasuk Indonesia, membuat kebijakan pembatasan sosial dan fisik diberlakukan untuk mengurangi penyebaran virus ini. Akibat dari dilakukannya isolasi sosial salah satunya adalah terjadi penurunan kondisi psikologis, yaitu depresi yang diakibatkan oleh kecemasan akan penyakit, rutinitas yang terganggu, dan kurangnya kontak sosial. Situasi yang tidak biasa membutuhkan trait positif optimisme karena individu yang optimis mengharapkan hasil akhir yang baik dalam setiap situasi. Oleh karena itu, penelitian ini bertujuan untuk mengetahui sejauh mana optimisme mampu menjadi mediator hubungan isolasi sosial dengan depresi pada masa pandemi Covid-19. Jenis penelitian ini kuantitatif dengan teknik analisis mediator. Instrumen pengambilan data dalam penelitian ini menggunakan tiga skala, yaitu Patient Reported Outcomes Measurement Information System (PROMIS) Social Isolation Short Form $4 a$ v2.0 untuk mengukur isolasi sosial, Center for Epidemiologic Studies Depression Scale (CESD-9) untuk mengukur depresi, dan Life Orientation TestRevised (LOT-R) untuk mengukur optimisme. Penelitian dilakukan terhadap 202 laki-laki dan perempuan, usia minimal 17 tahun, dan sedang menjalani situasi pembatasan sosial berskala besar (PSBB). Hasil penelitian menunjukkan bahwa terjadi indirect effect dengan nilai $\beta=0,12 ; \mathrm{SE}=0,04,(\mathrm{p}<0,05)$, pada variabel isolasi sosial dengan depresi melalui variabel optimisme, yang artinya optimisme dapat menjadi mediator hubungan isolasi sosial dengan depresi pada masa pandemi Covid-19.
\end{abstract}

Kata kunci: isolasi sosial; depresi; optimisme; pandemi Covid-19

\section{OPTIMISM AS A MEDIATOR OF THE RELATIONSHIP OF SOCIAL ISOLATION AND DEPRESSION DURING COVID-19 PANDEMIC}

\begin{abstract}
The Covid-19 pandemic that has hit almost all over the world, including Indonesia, has imposed social and physical restrictions in order to reduce the spread of this virus. As a result of social isolation, there is a decrease in psychological conditions, namely depression caused by anxiety about illness, disrupted routine, and lack of social contact. Unusual situations require a positive trait of optimism, because optimistic individuals expect good results in every situation. Therefore, the aim of this study is to determine the extent to which optimism is able to mediate the relationship between social isolation and depression during the Covid-19 pandemic. This type of research is quantitative with mediation analysis techniques. Three scales were used as instruments for data collection in this study: Patient Reported Outcomes Measurement Information System (PROMIS) Social Isolation Short Form 4a v2.0 to measure social isolation, Center for Epidemiologic Studies Depression Scale (CESD-9) to measure depression, and Life Orientation Test-Revised (LOT-R) to measure optimism. The study was conducted on 202 men and women, at least 17 years old, and currently undergoing a situation of large-scale social distancing (PSBB). The results of this study have an indirect effect with a value of $\beta=$ $0.12 ; \mathrm{SE}=0.04,(\mathrm{p}<0.05)$, at the social isolation variable with depression through the optimism variable, which means that optimism can mediate the relationship between social isolation and depression during the Covid-19 pandemic.
\end{abstract}

Keywords: social isolation; depression; optimism; Covid-19 pandemic 


\section{PENDAHULUAN}

Pandemi Covid-19 yang tiba-tiba terjadi di hampir seluruh belahan dunia, termasuk Indonesia, menimbulkan perubahan situasi baik secara fisik maupun psikologis. Perubahan yang terjadi secara tiba-tiba membuat penurunan kondisi psikologis di masyarakat. Setelah lima bulan pandemi Covid-19 masuk ke Indonesia, Perhimpunan Dokter Spesialis Kesehatan Jiwa Indonesia (2020) mengadakan layanan swaperiksa online masalah psikologis dan melaporkan bahwa dari total 4.010 orang yang melakukan swaperiksa depresi yang diakses di 34 provinsi, $62 \%$ diantaranya mempunyai masalah psikologis berupa depresi, dan $44 \%$ dari mereka merasa lebih baik mengakhiri hidupnya atau ingin melukai diri sendiri. Pikiran kematian terbanyak sebanyak $65 \%$ pada usia $18-29$ tahun.

Attachment theory oleh Bowlby (1969) menjadi salah satu dasar teori yang digunakan untuk menerangkan mengenai depresi. Menurut teori ini, depresi merupakan reaksi adaptif akibat kehilangan hubungan interpersonal sehingga terjadi reaksi sedih dan risau yang akhirnya membuat mood seseorang menurun. Selain hubungan interpersonal, kehilangan juga dapat berasal dari kehilangan pekerjaan, kebebasan, kesempatan pendidikan, rekreasi, kesempatan bersenang-senang, dan terputusnya dukungan (Kanter, Busch, Weeks, \& Landes, 2017).

Depresi berasal dari kata Latin depressare dan kata Latin deprimere yang artinya tertekan, meliputi rasa sedih, tidak berdaya, tidak mampu merasakan kesenangan dan kebahagiaan (Reevy, Ozer, \& Ito, 2010). Pada dasarnya, istilah depresi ini muncul untuk menunjukkan perasaan tertekan yang juga disebut sebagai sedih (Kanter et al., 2017). Depresi adalah gangguan mental umum yang muncul dengan suasana hati yang tertekan, kehilangan minat atau kesenangan, penurunan energi, perasaan bersalah atau harga diri rendah, gangguan tidur atau nafsu makan, dan konsentrasi yang buruk. Selain itu, depresi sering kali disertai dengan gejala kecemasan (Marcus, Yasamy, Van Ommeren, \& Chisholm, 2012). Depresi memengaruhi setiap orang dengan sebab yang berbeda, sehingga gejala yang disebabkan oleh depresi pun bervariasi dari orang ke orang. Warisan genetik, usia, jenis kelamin, dan latar belakang budaya memainkan peran dalam bagaimana depresi dapat memengaruhi seseorang (Bhowmik et al., 2012).

Depresi berat adalah gangguan suasana hati yang ditandai dengan rasa tidak mampu, putus asa, aktivitas menurun, pesimisme, anhedonia atau kehilangan minat pada hal-hal yang disenangi, dan kesedihan. Kombinasi gejala-gejala ini sangat mengganggu dan mempengaruhi kehidupan individu, kadang-kadang gangguan tersebut sangat kuat sehingga ada keinginan bunuh diri. Episode depresi yang melumpuhkan ini dapat terjadi sekali, dua kali atau beberapa kali seumur hidup (Iyer \& Khan, 2012). Sebaliknya ada juga depresi ringan atau dysthymia, kondisi seseorang yang selama kurang lebih dua tahun hampir setiap hari mengalami gangguan suasana hati padahal sebelumnya tidak pernah didiagnosis depresi berat, kurang semangat dalam menjalani aktivitas sehingga fungsi sebagai manusia tidak optimal walaupun gejala tidak separah depresi berat (Moch, 2011).

Pada masa pandemi, salah satu penyebab depresi adalah paparan berita-berita di media massa dengan narasi yang menakutkan mengenai bahaya dan ganasnya virus Covid-19 serta akibat-akibat buruk yang ditimbulkannya. Kabar simpang siur yang beredar mengenai kondisi pandemi yang beredar di masyarakat juga membuat resah. Hal ini sejalan dengan pendapat yang mengatakan bahwa perilaku verbal dapat mengganggu fungsi kognitif karena menimbulkan pemikiran negatif. Selanjutnya pemikiran dalam suatu kejadian dapat mempengaruhi perasaan dan menjadi penyebab munculnya depresi (Holmes et al., 2020).

Penyebab depresi bervariasi, perubahan situasi dan kondisi di lingkungan dan bagaimana cara meresponnya merupakan salah satu penyebab depresi yang disebut dengan reactive depression (Preston, O’Neal, \& Talaga, 2008). Kesehatan mental seseorang akan terganggu jika tidak dapat menyesuaikan diri dengan perubahan lingkungan di masa pandemi akibat diberlakukannya berbagai kebijakan dan pembatasan oleh pemerintah. Pendapat ini sesuai dengan pernyataan yang menyatakan bahwa depresi merupakan perilaku maladaptif akibat dari berubahnya lingkungan: lingkungan yang tidak normal dapat menyebabkan perilaku yang tidak normal pula (Kanter et al., 2017). 
Biasanya, manusia dapat melakukan rutinitas secara bebas dan melakukan interaksi sosial. Namun untuk mencegah penularan akibat virus corona, pemerintah Indonesia melarang mobilitas dan aktivitas dari satu wilayah ke wilayah lain yang disebut dengan pembatasan sosial berskala besar (PSBB) (Harsono, 2020). Di berbagai negara, masa karantina yang diberlakukan pada masa pandemi Covid-19 menimbulkan frustrasi. Rasa frustasi mengarah pada berbagai masalah psikologis, salah satunya adalah depresi. Masa penuh tekanan ini membuat konsumsi makanan dan minuman dengan gula tinggi meningkat, sehingga timbul istilah yang disebut dengan depreobesity (Mediouni, Madiouni, \& Kaczor-Urbanowicz, 2020).

Diberlakukannya isolasi sosial diketahui menyebabkan munculnya gejala-gejala depresi bagi orang yang sebelumnya sehat mental, apalagi bagi orang yang sudah mempunyai kecenderungan depresi, isolasi sosial dapat memicu munculnya depresi secara cepat dan berkelanjutan (Perrin, McCabe, Everly \& Links, 2009). Hal ini terjadi karena isolasi sosial membuat jenuh, komunikasi buruk, gangguan emosi, gangguan tidur, gangguan suasana hati, kesepian, dan ketakutan (Usher, Bhullar, \& Jackson, 2020). Efek negatif isolasi sosial dilaporkan terjadi di Iran. Masyarakat Iran merasa ketakutan dan kesepian dalam masa isolasi sosial akibat pandemi Covid-19 (Zandifar \& Badrfam, 2020). Selain itu, dijelaskan pula bahwa individu yang menjalani isolasi sosial atau karantina kehilangan hubungan face-to-face dan interaksi secara tradisional. Hal ini merupakan pengalaman yang menimbulkan stres (Zhang, Wu, Zhao, \& Zang, 2020).

Penelitian terdahulu mengenai isolasi sosial mengacu pada isolasi sosial yang terjadi karena seseorang terkena penyakit yang mengharuskannya untuk membatasi interaksi sosial. Pasien dengan gagal jantung yang mengalami isolasi sosial lebih berisiko untuk mengalami penurunan kesehatan dan risiko kematian (Manemann et al., 2018). Dalam hubungannya dengan teknologi, penggunaan media sosial yang berlebihan membuat seseorang merasa lebih terisolasi sosial dibandingkan orang yang lebih sedikit menggunakan media sosial (Whaite et al., 2018).

Selanjutnya, terdapat penelitian isolasi sosial dalam berbagai rentang usia berbeda. Tiwari \& Ruhela (2012) menyatakan bahwa remaja di Delhi yang kurang mampu menyesuaikan diri dengan teman sebaya memilih untuk melakukan isolasi sosial, yang pada akhirnya menyebabkan depresi. Remaja perempuan juga cenderung merasa depresi dibanding laki-laki. Kemudian, terdapat pula hubungan isolasi sosial dengan depresi pada usia lanjut (Santini et al., 2020). Taylor, Taylor, Nguyen, \& Chatters (2018) pun mengungkapkan bahwa isolasi sosial subjektif juga berpengaruh terhadap gejala depresi pada usia lanjut. Pada penelitian ini, isolasi sosial yang dimaksud adalah aturan PSBB yang dikeluarkan pemerintah. Kebijakan tersebut berlaku untuk semua lapisan masyarakat, baik sehat maupun sakit, dan semua rentang usia dibatasi ruang geraknya untuk bekerja, beribadah dan belajar dari rumah juga menghindari kerumunan.

Definisi isolasi sosial adalah suatu pembatasan secara fisik dan interaksi dengan orang lain yang diberlakukan karena seseorang terkena penyakit atau rentan terhadap penyakit (Manemann et al., 2018). Isolasi sosial menurut Carpenito-Moyet (2008) adalah keadaan ketika seseorang atau suatu kelompok mengalami atau merasakan kebutuhan atau keinginan untuk meningkatkan keterlibatan dengan orang lain, tetapi tidak dapat melakukan kontak tersebut. Primack et al. (2017) pun mengemukakan definisi lain dari isolasi sosial, yaitu keadaan di mana seorang individu merasa kurang memiliki hubungan sosial, keterlibatan nyata dengan orang lain, dan pemenuhan hubungan interpersonal, hal tersebut dikaitkan dengan peningkatan morbiditas dan mortalitas. National Institutes of Health (2020) mendefinisikan isolasi sosial sebagai persepsi mengenai rasa terhindar, dikeluarkan, terlepas, terputus dari, atau tidak diketahui oleh orang lain. Isolasi sosial dapat diterapkan sebagai akibat dari suatu penyakit atau ketidakmampuan seseorang menjalin hubungan dengan orang lain dan jelas tidaknya jaringan sosial. Ketidakmampuan ini membuat individu mempunyai hubungan interaksi sosial yang sedikit dan merasakan perasaan negatif akibat isolasi yang dilakukan (Shankar, 2018).

Isolasi sosial dapat merujuk pada isolasi sosial objektif atau subjektif. Isolasi sosial subjektif merupakan suatu kondisi ketika seseorang merasakan terisolasi secara sosial walaupun masih memiliki banyak ikatan sosial. Persepsi ini dapat melibatkan perasaan kesepian, tidak adanya dukungan, atau kurangnya keintiman yang dirasakan dalam hubungan interpersonal seseorang (Valtorta et al., 2016). Adapun isolasi sosial objektif mengacu pada isolasi fisik atau kurangnya interaksi sosial. Isolasi sosial objektif terjadi karena faktor 
situasional, salah satunya adalah struktur jaringan, seperti misalnya lingkaran pertemanan yang kecil, interaksi yang jarang terjadi, dan kurangnya partisipasi dalam kegiatan sosial dan kelompok (Holt-Lunstad et al., 2015).

Salah satu kekuatan psikologis yang diharapkan mampu untuk melawan depresi akibat isolasi sosial adalah optimisme. Individu yang optimis akan mampu menyesuaikan strategi coping mereka tergantung stressor, sehingga individu yang optimis lebih mampu mendapatkan hasil yang positif dibandingkan individu yang pesimis (Reed, 2016). Penelitian ini diperkuat dengan pendapat yang menyatakan bahwa optimisme dapat mengarah pada kesehatan mental yang kuat, serta sebagai sarana coping dalam menghadapi peristiwa negatif dalam hidup (Carver, Scheier, \& Segerstrom, 2010).

Penelitian mengenai optimisme dalam kondisi pandemi Covid-19 menemukan bahwa sumber daya psikologis seperti optimisme dan fleksibilitas psikologis merupakan unsur utama yang berkontribusi terhadap kesehatan mental selama terjadinya krisis kesehatan (Galić et al., 2020). Hal tersebut terbukti dalam penelitian yang menyatakan bahwa optimisme-pesimisme dan kondisi psikologis yang tidak fleksibel memediasi efek stres coronavirus pada masalah psikologis yang dialami orang dewasa di Turki. Optimisme-pesimisme disebutkan mampu memprediksikan masalah psikologis orang dewasa melalui kondisi psikologis yang tidak fleksibel (Arslan et al., 2020).

Adapun optimisme menurut Scheier \& Carver (1985) adalah suatu kecenderungan sifat untuk menilai masa depan berdasarkan terwujudnya hasil sesuai yang dinginkan, sedangkan pesimisme merupakan suatu kecenderungan sifat yang mengharapkan sesuatu yang buruk terjadi di masa depan. Optimisme adalah interpretasi seseorang pada situasi eksternal secara positif, di mana meskipun keadaan yang dihadapi bersifat merugikan, berbahaya, dan traumatis, kesulitan-kesulitan tersebut akan dapat dihadapi dengan usaha dan tekad (Carver, Scheier, \& Segerstrom, 2010).

Menurut Gordeeva, Sychev, \& Semenov (2020) terdapat dua jenis optimisme dalam menghadapi situasi yang mengancam hidup, yaitu defensive optimism dan constructive optimism. Defensive optimism adalah kecenderungan untuk percaya bahwa situasi yang ada tidak seburuk yang orang lain kira. Adapun constructive optimism mengacu kepada keyakinan bahwa diperlukan usaha untuk mengontrol perilaku.

Berdasarkan kerangka teoretis dan pemaparan di atas, maka penelitian ini bertujuan untuk mengetahui bahwa optimisme dapat menjadi mediator hubungan antara isolasi sosial dengan depresi di masa pandemi Covid-19. Selanjutnya, hipotesis yang diajukan penelitian ini adalah optimisme dapat menjadi mediator hubungan isolasi sosial dengan depresi pada masa pandemi Covid-19.

\section{METODE}

Metode penelitian yang digunakan adalah penelitian kuantitatif korelasional dengan menggunakan variabel mediator. Teknik pengambilan sampel yang digunakan dalam penelitian ini adalah quota sampling. Quota sampling dipertimbangkan karena adanya keterbatasan pada kesempatan, tenaga dan situasi. Quota sampling merupakan nonprobability sampling yang sering digunakan dalam survei, opini, dan jajak pendapat, dengan jumlah total orang yang akan menjadi sampel telah ditetapkan sebelumnya (Sedgwick, 2012). Pada penelitian ini, kuota sampel yang telah ditetapkan adalah sebanyak 200 subjek penelitian. Subjek penelitian yang digunakan dalam penelitian ini adalah sebanyak 202 orang berjenis kelamin laki-laki dan perempuan dengan usia minimal 17 tahun dan sedang menjalani karantina kesehatan akibat pandemi Covid-19.

Pengumpulan data dilakukan selama bulan Mei 2020, kurang lebih satu setengah bulan setelah masyarakat mendapat imbauan untuk bekerja, beribadah, dan bersekolah dari rumah yang dinyatakan pada tanggal 15 Maret 2020 oleh Presiden Jokowi di Istana Bogor (Ratriani, 2020). Dengan kondisi dan waktu yang ditetapkan dalam pengambilan data ini, diharapkan subjek penelitian sudah cukup menghayati fenomena pembatasan sosial akibat pandemi Covid-19, sehingga pengisian kuesioner menjadi lebih relevan. Mengingat masih diberlakukannya PSBB saat pengambilan data, pengisian kuesioner dilakukan secara daring menggunakan Google Form yang disebarkan melalui media sosial. Penelitian ini melibatkan tiga variabel, 
yaitu isolasi sosial sebagai variabel bebas, depresi sebagai variabel terikat, dan optimisme sebagai variabel intervening.

Pengumpulan data penelitian menggunakan tiga skala. Pertama, skala Center for Epidemiologic Studies Depression Scale (CES-D) untuk mengukur depresi. Alat ukur CES-D yang pertama kali dikembangkan oleh Radloff (1977) terdiri dari empat faktor yaitu rasa tertekan, tidak adanya afeksi positif, minimnya aktivitas, dan masalah interpersonal. CESD-9 memiliki reliabilitas $\alpha=0,817$, yang artinya alat ukur ini memiliki reliabilitas sangat baik.

Kedua, skala Patient Reported Outcomes Measurement Information System (PROMIS) Social Isolation Short Form 4a v2.0 yang dikembangkan oleh Cella et al. (2007) untuk National Institutes of Health dengan domain kesehatan fisik, mental, dan sosial. Namun pada penelitian ini, penggunaan alat ukur tersebut difokuskan pada domain kesehatan sosial dengan subdomain mengenai isolasi sosial. PROMIS Social Isolation Short Form 4a v2.0 mendapatkan reliabilitas $\alpha=0,716$, atau dengan kata lain memiliki reliabilitas baik.

Skala ketiga yaitu skala Life Orientation Test-Revised (LOT-R) dikembangkan oleh Scheier, Carver, \& Bridges (1994) yang terdiri dari aspek optimisme dan pesimisme untuk mengukur optimisme. LOT-R memiliki reliabilitas $\alpha=0,627$, yang berarti menunjukkan bahwa reliabilitasnya cukup baik.

Uji hipotesis penelitian ini menggunakan pendekatan transmittal approach, yaitu $\mathrm{M}$ menjadi mediator hubungan $\mathrm{X}$ dan $\mathrm{Y}$. Dengan kata lain, terdapat hubungan tidak langsung antara $\mathrm{X}$ dan $\mathrm{Y}$ melalui $\mathrm{M}$ (Rungtusanatham, Miller, \& Boyer, 2014). Analisis data menggunakan mediation analysis dilakukan dengan bantuan program JASP versi 0.11.1.

\section{HASIL DAN PEMBAHASAN}

Tabel 1 menyajikan karakteristik demografis subjek dalam penelitian ini yang meliputi jenis kelamin, status pernikahan, tempat tinggal, usia, dan pekerjaan. Berdasarkan Tabel 1, diketahui berdasarkan jenis kelamin jumlah perempuan lebih banyak, yaitu 76,7\%, laki-laki 23,3\%. Berdasarkan status pernikahan, dominan yang belum menikah sebanyak $76,7 \%$, yang bercerai hanya $1 \%$. Mayoritas $86,1 \%$ tinggal bersama keluarga selebihnya tinggal sendiri $8,4 \%$, atau bersama teman/lainnya $5,4 \%$. Selanjutnya usia yang paling banyak adalah usia 17-25 tahun dengan presentase 60,9\%, sedangkan usia 45 keatas 5\%. Berdasarkan aktivitas sehari-hari status mahasiswa paling banyak sebesar 52,5\%, diikuti dengan karyawan sebanyak 34\%.

Tabel 1. Karakteristik Demografis Subjek Penelitian

\begin{tabular}{lcc}
\hline Karakteristik & $\mathrm{N}$ & $\%$ \\
\hline Jenis kelamin & & \\
Laki-laki & 47 & 23,3 \\
$\quad$ Perempuan & 155 & 76,7 \\
\hline Status Pernikahan & & \\
$\quad$ Menikah & 45 & 22,3 \\
$\quad$ Belum menikah & 155 & 76,7 \\
$\quad$ Cerai & 2 & 1 \\
\hline Tempat Tinggal & & \\
Bersama keluarga & 174 & 86,1 \\
Sendiri & 17 & 8,4 \\
Bersama teman/lainnya & 11 & 5,4 \\
\hline Usia & & \\
17-25 tahun & 123 & 60,9 \\
26-35 tahun & 52 & 25,7 \\
36-45 tahun & 17 & 8,4 \\
$\quad$ 45 tahun & 10 & 5 \\
\hline Pekerjaan & & \\
Mahasiswa/ pelajar & 106 & 52,2 \\
\hline
\end{tabular}




\begin{tabular}{lll}
\hline Karyawan/ pegawai & 70 & 34,7 \\
Lainnya & 26 & 12,9 \\
\hline
\end{tabular}

Tabel 2 menyajikan uji hipotesis mediation analysis optimisme sebagai mediator hubungan isolasi sosial dengan depresi. Berdasarkan hasil penelitian diketahui terjadi indirect effect dengan nilai $\beta=0,12 ; \mathrm{SE}=$ 0,04, $(\mathrm{p}<0,05)$, yang artinya optimisme dapat menjadi mediator hubungan isolasi sosial dengan depresi pada masa pandemi Covid-19. Kemudian CI 95\% menunjukkan pada indirect effect lebih rendah $(0,05-019)$ dibanding direct effect $(0,51-0,85)$. Artinya ketika optimisme dimasukan sebagai mediator, maka nilai depresi menjadi lebih rendah, di sisi lain tanpa adanya optimisme nilai depresi lebih tinggi.

Selanjutnya, ditemukan direct effect dengan hasil $\beta=0,68 ; \mathrm{SE}=0,08,(\mathrm{p}<0,05)$, yang artinya ada hubungan secara langsung antara isolasi sosial dengan depresi pada masa pandemi Covid-19. Adapun pada total effect, diperoleh nilai $\beta=0,80 ; \mathrm{SE}=0,09,(\mathrm{p}<0,05)$, dengan CI 95\% $(0,63-0,97)$. Berdasarkan hasil yang telah dipaparkan, maka pengaruh langsung dan tidak langsung secara bersama-sama mampu menerangkan terjadinya hubungan antara isolasi sosial dengan depresi melalui optimisme sebagai mediator.

Hasil penelitian di atas sejalan dengan penelitian yang menyatakan bahwa pada saat menjalani isolasi sosial, akan timbul kesepian yang akhirnya menyebabkan depresi. Untuk mengatasinya, diperlukan aktivitas di waktu luang sehingga optimisme akan terbentuk dan dapat meningkatkan well-being (Kim et al., 2017; Matthews et al., 2016). Penelitian selanjutnya pada mahasiswa menyatakan bahwa dalam situasi yang tidak terduga, seperti datangnya pandemi Covid-19, diperlukan optimisme sebagai sarana resiliensi dalam menghadapi situasi yang menantang ini (Maheshwari \& Jutta, 2020).

Penelitian ini juga didukung penelitian yang dilakukan lintas negara yang menyatakan bahwa selama pandemi, berbagai negara diberlakukan lockdown sehingga membuat ketidakpastian ekonomi, terbatasnya hubungan dengan teman dan keluarga, dan screen time yang meningkat. Hal tersebut dapat meningkatkan resiko depresi (Płomecka et al., 2020). Menjadi pribadi yang optimis dibarengi dengan kepercayaan terhadap orang lain, dan tidak percaya teori konspirasi mengenai Covid-19 membuat individu mengembangkan perilaku mencegah penularan penyakit Covid-19 (Jovančević \& Milićević, 2020).

Tabel 2. Mediation Analysis Optimisme sebagai Mediator Hubungan Isolasi Sosial dengan Depresi

\begin{tabular}{lccccc}
\hline Variabel & SE & $\mathrm{B}$ & $P$ & \multicolumn{2}{c}{$95 \%$ CI } \\
\cline { 5 - 6 } & & & & Lower & Upper \\
\hline $\begin{array}{l}\text { Direct effect } \\
\text { Isolasi sosial } \rightarrow \text { depresi }\end{array}$ & 0,08 & 0,68 & 0,000 & 0,51 & 0,85 \\
\hline $\begin{array}{l}\text { Indirect effect } \\
\quad \text { Isolasi sosial } \rightarrow \text { optimisme } \rightarrow \text { depresi }\end{array}$ & 0,04 & 0,12 & 0,000 & 0,05 & 0,19 \\
\hline $\begin{array}{l}\text { Total effect } \\
\text { Isolasi sosial } \rightarrow \text { depresi }\end{array}$ & 0,09 & 0,80 & 0,000 & 0,63 & 0,97 \\
\hline
\end{tabular}

Selanjutnya menurut penelitian, rasa takut saat pandemi Covid-19 akan menimbulkan kecemasan dan depresi sehingga membutuhkan trait positif seperti optimisme untuk melindungi diri dari menurunnya kesehatan mental akibat Covid-19 (Vos et al., 2020). Dikembangkannya optimisme pada diri individu dapat mengurangi beban psikologis, seperti kecemasan dan ketakutan akibat dari Covid-19. Selain itu optimisme juga mengarah kepada perilaku positif lain seperti kemampuan untuk menyaring berita, karena orang yang optimis memilih berita baik untuk di konsumsi sehingga tidak mudah dipengaruhi berita bohong dan menakutnakuti (Eva, Sari, Andini, \& Mahasin, 2021). Perilaku mematuhi peraturan di masa pandemi memerlukan adaptasi, optimisme merupakan coping untuk beradaptasi dan menjadi salah satu faktor untuk mematuhi himbauan untuk di rumah saja selama masa isolasi sosial pandemi Covid-19 (Gordeeva, Sychev, \& Semenov, 2020). 
Hubungan langsung antara isolasi sosial dengan depresi sejalan dengan penelitian yang menyatakan bahwa gejala depresi ditemukan lebih tinggi pada subjek penelitian yang terisolasi secara sosial, baik dari teman maupun kerabat (Ge, Yap, Ong, \& Heng, 2017). Isolasi sosial mengakibatkan kesepian yang beriringan dengan kecemasan, depresi, meningkatnya pemakaian zat-zat terlarang, dan dengan ditutupnya sekolah pelecehan seks pada anak akan meningkat (Galea, Merchant, \& Lurie, 2020). Selanjutnya, isolasi sosial sebagai salah satu cara untuk mencegah terjadinya penularan Covid-19 ternyata menciptakan masalah baru yang tidak dapat dihindari, seperti terputusnya hubungan, sosial, merasa diri tidak berguna, terjebak, terbebani secara ekonomi, pengangguran, kemiskinan, dan kekurangan uang. Situasi ini mengakibatkan masalah kesehatan mental, seperti perasaan negatif dan dapat memicu depresi (Holmes et al., 2020). Gejala seperti kecemasan, depresi, takut, stress dan sulit tidur dilaporkan lebih sering terjadi saat pandemi Covid-19 (Torales, O'Higgins, Castaldelli-Maia, \& Ventriglio, 2020).

\section{SIMPULAN}

Berdasarkan uraian analisis uji hipotesis di atas, dapat diambil kesimpulan bahwa optimisme dapat menjadi mediator hubungan isolasi sosial dengan depresi pada masa pandemi Covid-19. Efek langsung antara variabel bebas dan variabel terikat juga ditemukan. Artinya, isolasi sosial dapat menimbulkan depresi bagi individu pada masa pandemi Covid-19. Berdasarkan hasil penelitian, diperlukan monitoring dan laporan mengenai tingkat kecemasan, depresi, menyakiti diri sendiri, dan masalah kesehatan mental lainnya untuk mengembangkan bentuk intervensi yang tepat, juga menentukan pelaksanaan intervensi yang akan dilakukan secara online atau offline sehingga evaluasi dapat dilakukan secara optimal.

Selain itu, pengurangan konsumsi berita secara berlebihan dan pemilihan saluran informasi yang dapat dipercaya dapat dilakukan agar tidak mudah terprovokasi oleh narasi yang menyesatkan. Kemudian, bersikap terbuka dan mengembangkan kemampuan untuk tetap berkomunikasi dengan rekan kerja, teman dan keluarga dibantu teknologi komunikasi yang ada. Penggunaan teknologi digital dapat menjembatani interaksi sosial walaupun terpisah jarak sehingga muncul perasaan tidak sendirian dan terhubung dengan orang lain. Menaruh kepercayaan kepada pihak yang berwenang untuk mengatasi pandemi Covid-19 juga dapat dilakukan. Perasaan bahwa pandemi telah ditangani oleh ahlinya diharapkan mampu membuat perasaan tenang dan mengurangi rasa tertekan.

Optimisme merupakan potensi dalam psikologis individu yang secara tidak langsung mampu memperkuat atau memperlemah depresi. Maka untuk menumbuhkan optimisme, individu dapat melakukan pendekatan spiritual dan religiusitas untuk melihat kejadian seburuk apapun pasti ada hikmahnya, dan bersyukur atas apa yang dimiliki saat ini. Perlu untuk berpikir positif untuk masa depan dan terhadap kejadian yang tidak terduga dalam hidup.

Menurut penelitian ini, diketahui bahwa optimisme mampu menjembatani depresi yang disebabkan isolasi sosial menjadi lebih rendah. Namun perlu diperhatikan bahwa jangan sampai terjadi bias optimistik, yaitu kondisi yang dapat membuat seseorang merasa tidak percaya bahwa virus Covid-19 dapat menginfeksi dirinya. Hal tersebut dapat membuat kepatuhan seseorang dalam menjalani protokol kesehatan menurun. Bias optimistik juga bisa terjadi pada tataran pembuat kebijakan, seperti pemerintah. Jika pemerintah terlalu optimis, akan terjadi kesalahan perencanaan (planning fallacy), yakni kecenderungan mengabaikan realitas yang ada di masyarakat dan kurang tepat mengukur kemampuan dalam menyelesaikan masalah pandemi Covid-19, sehingga kebijakan yang diambil menjadi tidak konsisten dan kurang tepat sasaran.

Selain itu, direkomendasikan untuk mengurangi depresi dengan menggunakan sumber dari luar diri individu seperti dukungan sosial dari keluarga, teman, atau orang lain yang dianggap penting. Perilaku prososial dan altruisme juga perlu dikembangkan di masyarakat. Salah satu cara yang dapat dilakukan adalah memberdayakan lingkungan setingkat RT/RW untuk saling bantu membantu tetangga yang kesulitan dan saling mendukung dalam menghadapi pandemi ini. Hal ini dapat menumbuhkan perasaan diperhatikan dan dapat meringankan beban bagi orang yang terdampak pandemi Covid-19. 
Penelitian ini hanya mengkaji hubungan antara isolasi sosial dan depresi yang dimediasi oleh optimisme. Belum ada penjelasan mengenai perbedaan tingkat depresi dan bentuk isolasi sosial subjektif atau objektif yang mempengaruhi depresi tidak disebutkan. Diharapkan penelitian selanjutnya juga dapat menambahkan variabelvariabel atribut demografis sebagai data tambahan analisis. Selain itu, penelitian dapat dilakukan pada kelompok rentan, seperti orang yang sudah memiliki masalah kesehatan mental sebelumnya, tenaga kesehatan, lansia dan kelompok tertentu seperti di penjara, perkampungan kumuh, atau perumahan elit.

\section{DAFTAR PUSTAKA}

Arslan, G., Yıldırım, M., Tanhan, A., Buluş, M., \& Allen, K. A. (2020). Coronavirus stress, optimismpessimism, psychological inflexibility, and psychological health: Psychometric properties of the coronavirus stress measure. International Journal of Mental Health and Addiction.

Bhowmik, D., Kumar, K. P., Srivastava, S., Paswan, S., \& Dutta, A. S. (2012). Depression -symptoms, causes, medications and therapies. The Pharma Innovation, 1, (3), 41-55.

Bowlby J. (1969). Attachment. Attachment and loss: Vol. 1. Loss. New York: Basic Books.

Carpenito-Moyet, L. J. (2008). Handbook of nursing diagnosis (12th ed.). Philadelphia: Lippincott Williams $\&$ Wilkins.

Carver, C. S., Scheier, M. F., \& Segerstrom, S. C. (2010). Optimism. Clinical Psychology Review, 30, (7), 879-889.

Cella, D., Yount, S., Rothrock, N., Gershon, R., Cook, K., Reeve, B., Ader, D., Fries, J. F., Bruce, B., \& Rose, M. (2007). The Patient-Reported Outcomes Measurement Information System (PROMIS). Medical Care, 45, (5), S3-S11.

Eva, N., Sari, Q. A.F., Andini, R. D., \& Mahasin, A. Z. (2020). The Role of Optimism in Responding to Covid19 in International Conference of Psychology. KnE Social Sciences, 365-369.

Galea, S., Merchant, R.M., Lurie, N. (2020). The Mental Health Consequences ofCOVID-19 and Physical Distancing The Need for Prevention and Early Intervention. American Medical Association, 10.

Galić, M., Mustapić, L., Šimunić, A., Sić, L., \& Cipolletta, S. (2020). COVID-19 Related Knowledge and Mental Health: Case of Croatia. Frontiers in Psychology, 11, 1-11.

Ge, L., Yap, C. W., Ong, R., \& Heng, B. H. (2017). Social isolation, loneliness and their relationships with depressive symptoms: A population-based study. PLoS ONE, 12, (8), 1-13.

Gordeeva, T. O., Sychev, O. A., \& Semenov I, Y. (2020). Constructive optimism, defensive optimism, and gender as predictors of autonomous motivation to follow stay-at-home recommendations during the Covid-19 pandemic. Psychology in Russia-State of the Art, 13, (4,), 38-54.

Harsono, F.H. (4 April, 2020). Pembatasan sosial berskala besar dan karantina wilayah, apa bedanya?. https://www.liputan6.com/health/read/4218988/pembatasan-sosial-berskala-besar-dan-karantinawilayah-apa-bedanya

Holmes, E. A., O’Connor, R. C., Perry, V. H., Tracey, I., Wessely, S., Arseneault, L., Ballard, C., Christensen, H., Cohen Silver, R., Everall, I., Ford, T., John, A., Kabir, T., King, K., Madan, I., Michie, S., Przybylski, A. K., Shafran, R., Sweeney, A., ... Bullmore, E. (2020). Multidisciplinary research priorities for the Covid-19 pandemic: A call for action for mental health science. The Lancet Psychiatry, 7, (6), 547-560.

Holt-Lunstad, J., Smith, T. B., Baker, M., Harris, T., \& Stephenson, D. (2015). Loneliness and social isolation as risk factors for mortality a meta-analytic review. Perspectives on Psychological Science, 10 (2), 227-237.

Iyer, K., \& Khan, Z. A. (2012). Depression - A review. Research Journal and Recent Sciences, 1, (4), $79-87$.

Jovančević, A., \& Milićević, N. (2020). Optimism-pessimism, conspiracy theories and general trust as factors 
contributing to COVID-19 related behavior - A cross-cultural study. Personality and Individual Differences, 167, 110216.

Kanter, J. W., Busch, A. M., Weeks, C. E., \& Landes, S. J. (2017). The nature of clinical depression: Symptoms, syndromes, and behavior analysis. The Behavior Analyst, 31, (1), 1-21.

Kim, J., Lee, S., Chun, S., Han, A., \& Heo, J. (2017). The effects of leisure-time physical activity for optimism, life satisfaction, psychological well-being, and positive affect among older adults with loneliness. Annals of Leisure Research, 20, (4), 406-415.

Maheshwari, D. A., \& Jutta, M. V. (2020). Study of relationship between optimism and resilience in the times of COVID-19 among university students. The International Journal of Indian Psychology, 8, (3).

Manemann, S. M., Chamberlain, A. M., Roger, V. L., Griffin, J. M., Boyd, C. M., Cudjoe, T. K. M., Jensen, D., Weston, S. A., Fabbri, M., Jiang, R., \& Rutten, L. J. F. (2018). Perceived social isolation and outcomes in patients with heart failure. Journal of the American Heart Association, 7, (11), 1-7.

Marcus, M., Yasamy, M. T., van Ommeren, M., \& Chisholm, D. (2012). Depression: A global public health concern. WHO Department of Mental Health and Substance Abuse, 6-8.

Matthews, T., Danese, A., Wertz, J., Odgers, C. L., Ambler, A., Moffitt, T. E., \& Arseneault, L. (2016). Social isolation, loneliness and depression in young adulthood: A behavioural genetic analysis. Social Psychiatry and Psychiatric Epidemiology, 51, (3), 339-348.

Mediouni, M, Madiouni, R, \& Kaczor-Urbanowicz, K. E. (2020). Covid-19: How the quarantine could lead to the depreobesity. Obesity Medicine, 19.

Moch, S. (2011). Dysthymia: More than Minor Depression. South African pharmaceutical journal. SuidAfrikaanse tydskrif vir apteekwese, 78, (3), 38-43.

National Institute of Health. (2020). PROMIS: List of adult measure. https://www.healthmeasures.net/exploremeasurement-systems/promis/intro-to-promis/list-of-adult-measures

Perhimpunan Dokter Spesialis Kedokteran Jiwa Indonesia. (2020). 5 bulan pandemi Covid-19 di Indonesia. http://pdskji.org/home

Perrin, P. C., McCabe, O. L., Everly, G. S., \& Links, J. M. (2009). Preparing for an influenza pandemic: mental health considerations. Prehospital and Disaster Medicine, 24, (3), 223-230.

Płomecka, M. B., Gobbi, S., Neckels, R., Radziński, P., Skórko, B., Lazzeri, S., Almazidou, K., Dedić, A., Bakalović, A., Hrustić, L., Ashraf, Z., Haghi, S. E., Rodríguez-Pino, L., Waller, V., Jabeen, H., Alp, A. B., Behnam, M. A., Shibli, D., Barańczuk - Turska, Z., ... Jawaid, A. (2020). Mental health impact of Covid-19: A global study of risk and resilience factors. medRxiv, 1-45.

Preston, J. D., O'Neal, J. H., \& Talaga, M. C. (2008). Handbook of clinical psychopharmacology for therapists (5th ed.). New Harbinger Publications

Primack, B. A., Shensa, A., Sidani, J. E., Whaite, E. O., Lin, L. yi, Rosen, D., Colditz, J. B., Radovic, A., \& Miller, E. (2017). Social media use and perceived social isolation among young adults in the U.S. American Journal of Preventive Medicine, 53, (1), 1-8.

Radloff, L. (1977). The CES-D scale: A self-report depression scale for research in the general population. Applied Psychological Mesurement, 1, (3), 385-401.

Ratriani, V. R. (2020). Jokowi instruksikan bekerja dari rumah, ini arti work from home. https://www.kompas.com/tren/read/2020/03/16/195035165/jokowi-instruksikan-bekerja-dari-rumahini-arti-work-from-home?page=all

Reed, D. J. (2016). Coping with occupational stress: The role of optimism and coping flexibility. Psychology Research and Behavior Management, 9, 71-79.

Reevy, G. M., \& Ozer, Y. M., \& Ito, Y. (Collaborators). (2010). Encyclopedia of emotion, Vol. 2. Greenwood Press/ABC-CLIO. 192.

Rungtusanatham, M., Miller, J. W., \& Boyer, K. K. (2014). Theorizing, testing, and concluding for mediation in SCM research: Tutorial and procedural recommendations. Journal of Operations Management, 32, (3), 99-113.

Santini, Z. I., Jose, P. E., York Cornwell, E., Koyanagi, A., Nielsen, L., Hinrichsen, C., Meilstrup, C., Madsen, 
K. R., \& Koushede, V. (2020). Social disconnectedness, perceived isolation, and symptoms of depression and anxiety among older Americans (NSHAP): A longitudinal mediation analysis. The Lancet Public Health, 5, (1), 62-70.

Scheier, M. F., \& Carver, C. S. (1985). Optimism, coping, and health: Assessment and implication of generalized outcome expectancies. Health Psychology, 4, (3), 219-247.

Scheier, M. F., C. S. Carver, and M. W. Bridges. (1994). "Distinguishing Optimism from Neuroticism (and Trait Anxiety, Self-mastery, and Self-esteem): A Reevaluation of the Life Orientation Test." Journal of Personality and Social Psychology, 67, (6), 1063-1078.

Sedgwick, P. (2012). Proportional quota sampling. BMJ, 345.

Shankar, A. (2018). Social isolation. In Bornstein, M. H. (ed.), The SAGE encyclopedia of lifespan human development.

Taylor, H. O., Taylor, R. J., Nguyen, A. W., \& Chatters, L. (2018). Social isolation, depression, and psychological distress among older adults. Journal Aging Health, 30, (2), 229-246.

Tiwari, P., \& Ruhela, S. (2012). Social isolation \& depression among adolescent: A comparative perspective. 2nd International Conference on Social Science and Humanity, 31, 249-253.

Torales, J., O’Higgins, M., Castaldelli-Maia, J. M., \& Ventriglio, A. (2020). The outbreak of Covid-19 coronavirus and its impact on global mental health. International Journal of Social Psychiatry, 66, (4), 317-320.

Usher, K., Bhullar, N., \& Jackson, D. (2020). Life in the pandemic: Social isolation and mental health. Journal of Clinical Nursing, 29, (15-16), 2756-2757.

Valtorta, N. K., Kanaan, M., Gilbody, S., Ronzi, S., \& Hanratty, B. (2016). Loneliness and social isolation as risk factors for coronary heart disease and stroke: Systematic re- view and meta-analysis of longitudinal observational studies. Heart, 102, (13), 1009-1016.

Vos, L. M. W., Habibović, M., Nyklíček, I., Smeets, T., \& Mertens. G. (2020). Optimism, mindfulness, and resilience as potential protective factors for the mental health consequences of fear of the coronavirus. Psychiatry Research, 300, 1-8.

Whaite, E. O., Shensa, A., Sidani, J. E., Colditz, J. B., \& Primack, B. A. (2018). Social media use, personality characteristics, and social isolation among young adults in the United States. Personality and Individual Differences, 124, 45-50.

Zandifar, A., \& Badrfam, R. (2020). Iranian mental health during the Covid-19 epidemic. Asian Journal of Psychiatry, 51.

Zhang, J., Wu, W., Zhao, X., \& Zhang, W. (2020). Recommended psychological crisis intervention response to the 2019 novel coronavirus pneumonia outbreak in China: A model of West China Hospital. Precision Clinical Medicine, 1-6. 